\title{
NORMAL CEREBROSPINAL FLUID VALUES IN FULL-TERM GESTATION AND PREMATURE NEONATES
}

\author{
CRISTIANA M.C. NASCIMENTO-CARVALHO*, OTÁVIO A. MORENO-CARVALHO**
}

\begin{abstract}
Results of cerebrospinal fluid (CSF) examinations from 77 high-risk neonates were reviewed. The mean CSF white cells (WBC) count was 4.5 cell $/ \mathrm{mm}^{3}$, being two standard deviations above the mean 11.7 cells/ $\mathrm{mm}^{3}$ in the full-term gestation neonate group; in the premature neonate one, the mean CSF WBC count was 5.1 cells $/ \mathrm{mm}^{3}$, being two standard deviations above the mean 16.7 cell $/ \mathrm{mm}^{3}$. PMNs (polymorphonuclear leukocytes) were present in less than $40 \%$ of those children, being the mean PMN percentage $4.2 \%$ and $0.6 \%$, the mean ANC (absolute neutrophil count) was $0.3 / \mathrm{mm}^{3}$ and $0.06 / \mathrm{mm}^{3}$, in full-term gestation neonate group and premature neonate one, respectively. The mean CSF protein concentration is significantly greater in those premature neonates (101.2 $\mathrm{mg} / \mathrm{dl})$ compared with that in term neonates $(77.6 \mathrm{mg} / \mathrm{dl})$. The average glucose was just the same in both groups (67 $\mathrm{mg} / \mathrm{dl}$ ). All of these values were from patients who underwent nontraumatic cisternal puncture, with no red blood cells $\left(\mathrm{RBC} / \mathrm{mm}^{3}=0\right)$. Traumatic puncture, even up to $500 \mathrm{RBC} / \mathrm{mm}^{3}$, interfered on CSF parameters.
\end{abstract}

KEY WORDS: cerebrospinal fluid, neonate, cisternal puncture, normal values.

\section{Valores normais do líquido cefalorraqueano em recém-nascidos a termo e prematuros}

RESUMO - Os resultados do estudo do líquido cefalorraqueano realizado em 77 recém-nascidos de alto risco foram revistos. A média da celularidade foi 4,5 células $/ \mathrm{mm}^{3}$, sendo a soma da média mais 2 desvios-padrão 11,7 células $/ \mathrm{mm}^{3}$ no grupo de crianças a termo; no grupo de crianças prematuras, a média da celularidade foi 5,1 células $/ \mathrm{mm}^{3}$, sendo a soma da média mais 2 desvios-padrão 16,7 células $/ \mathrm{mm} 3$. Neutrófilos estavam presentes em menos de $40 \%$ dos exames, sendo a média do percentual de neutrófilos 4,2\% e 0,6\% e a média da contagem absoluta de neutrófilos $0,3 / \mathrm{mm}^{3}$ e $0,06 / \mathrm{mm}^{3}$, no grupo de crianças a termo e no grupo de crianças prematuras, respectivamente. A média da proteína foi maior entre os prematuros $(101,2 \mathrm{mg} / \mathrm{dl})$ quando comparada com a média da proteína entre os recém-nascidos a termo $(77,6 \mathrm{mg} / \mathrm{dl})$, sendo a diferença estatisticamente significante. A média da glicose foi a mesma nos 2 grupos $(67 \mathrm{mg} / \mathrm{dl})$. Todos estes valores foram decorrentes da análise de exames sem acidente de punção (hemácias $/ \mathrm{mm}^{3}=0$ ). Acidente de punção, mesmo com hemácias $\leq 500 / \mathrm{mm}^{3}$, interfere nos parâmetros do líquor.

PALAVRAS-CHAVE: líquido cefalorraqueano, recém-nascido, punção cisternal, valores normais.

Evaluation of the cerebrospinal fluid (CSF) white blood cell (WBC) count and glucose and protein concentrations is used to assess the probability of the presence of central nervous system (CNS) infection, mainly bacterial, viral and fungal meningitis ${ }^{1,2}$. Although normal values are well established for CSF cell counts and protein and glucose contents in children and adults, this is not the case for neonates ${ }^{3,4}$. Several studies have been conducted in order to determine the range of normal cellularity in noninfected CSF neonates but shortcomings of their methodology were: the inclusion of cases with traumatic lumbar puncture (LP) $)^{1,4-7}$, and performance before the availability of modern obstetrical and neonatal intensive care facilities ${ }^{7-14}$ which have resulted in survival of a large number of infants who are at high-risk of developing systemic bacterial diseases because of

*Serviço de Pediatria, Hospital Universitário Professor Edgard Santos, Universidade Federal da Bahia, Brasil: Professor Assistente; **Laboratório de Liquorologia (LCR) da Fundacão José Silveira, Salvador, Bahia, Brasil: Médico Liquorologista. Aceite: 23-março-1998.

Dra. Cristiana Nascimento-Carvalho - Rua Aristides Novis 105/1201B - 40210-630 Salvador BA - Brasil. FAX 071235 7869. E-mail: otaviocr@svn.com.br 
obstetrical complications, prematurity, and invasive procedures utilized in their management. There is no specific information regarding the range of CSF values in high-risk full-term gestation (Tn) and preterm (Ptn) neonates with noninfected CSF obtained by nontraumatic puncture, with no red blood cells $\left(\mathrm{RBC} / \mathrm{mm}^{3}=0\right)$.

The purpose of this study is to evaluate the composition of noninfected CSF obtained by nontraumatic cisternal puncture $\left(\mathrm{RBC}=0 / \mathrm{mm}^{3}\right)$ in neonates (age $\leq 28$ days), specifically distinguishing CSF profiles of those full-term gestation infants compared with those premature infants, and to compare CSF values between nontraumatic and traumatic puncture up to 500 red blood cells $(\mathrm{RBC}) / \mathrm{mm}^{3}$ in full-term gestation infant and in premature infant group.

\section{MATERIAL AND METHODS}

We retrospectively reviewed the CSF charts of all newborn babies who underwent cisternal puncture between October 1988 and September 1992 at the CSF Laboratory (LCR), José Silveira Foundation, Salvador, Bahia, Brazil. Examination of the CSF was performed by routine procedures: for cell count (cells $/ \mathrm{mm}^{3}$ ) FuchsRosenthal chamber was used; for cytomorphological profile, accelerated gravitational sedimentation technique and Leishman staining were proceeded; for protein concentration $(\mathrm{mg} / \mathrm{dl})$ the trichloride acetic acid method was used; for glucose concentration $(\mathrm{mg} / \mathrm{dl})$ the enzymatic method, according to Trinder, was used. From that group of patients, we selected infants who met the following criteria for inclusion in this study: (1) age up to 28 days, (2) absence of CNS hemorrhage, (3a) nontraumatic puncture $\left(\mathrm{RBC}=0 / \mathrm{mm}^{3}\right)$, or (3b) traumatic puncture up to $500 \mathrm{RBC} / \mathrm{mm}^{3}$, (4) accessible clinical data. Hemorrhagic CSF sample was defined as: presence of RBC in different degrees of degeneration and/ or presence of RBC containing macrophages. From those selected patients, clinical information was obtained retrospectively from chart review and those ones who did not have any evidence of CNS or congenital infection were eligible for this study.

The CSF WBC and differential cell counts, protein and glucose concentrations were recorded as well as age, gestational age, the reason the CSF examination was performed, final diagnosis and evolution. Full-term gestation infant was the one whose gestational age was equal to or greater than 38 weeks. The means, medians, standard deviations and the $90^{\text {th }}$ percentile of the frequencies were calculated for WBC count, polymorphonuclear leukocyte (PMN) percentage, absolute neutrophil count (ANC), protein and glucose concentrations.

The means and standard deviations for full-term gestation neonates were compared with those for preterm neonates, using $t$ test; the proportions for PMN presence were compared by using the chi square test or Fisher's exact test. A similar analysis was performed by comparing results from nontraumatic with results from traumatic $\left(\mathrm{RBC} \leq 500 / \mathrm{mm}^{3}\right)$ punctures, in the full-term gestation neonate and in the premature neonate group.

\section{RESULTS}

A cisternal puncture was performed on 144 neonates during the studied period; 67 patients were excluded due to hemorrhagic CSF $(\mathrm{N}=32)$, traumatic puncture over $500 \mathrm{RBC} / \mathrm{mm}^{3}(\mathrm{~N}=18)$, congenital syphilis $(\mathrm{N}=4)$, congenital rubella $(\mathrm{N}=1)$, bacterial $\mathrm{CNS}$ infection $(\mathrm{N}=6): 4$ children with Gram-negative bacterial meningitis (Moraxella sp., E. coli, E. cloacae, P. aeruginosa), 2 children with purulent CSF from which no organism was isolated; age over 28 days $(\mathrm{N}=3)$, no clinical data available $(\mathrm{N}=3)$, the criteria for this study were satisfied by 77 of those patients. Cytomorphological profile was not performed in 1 full-term gestation neonate and in 2 premature neonates; protein and glucose concentrations were not performed in 1 premature neonate.

With regard to the full-term child group, nontraumatic puncture, the age ranged between 1 and 24 days, being the median 5 days. CSF examination was performed on account of probable infection, whether due to fever presence, leukocytosis or leukopenia in $54.2 \%$ (13/24) of the patients; 10 children had proved infection: sepsis was diagnosed in $16.7 \%(4 / 24)$ of the cases, and restricted infection like pneumonia $(\mathrm{N}=4)$, bacterial dermatitis $(\mathrm{N}=1)$, necrotizing enterocolitis $(\mathrm{N}=1)$ in $25.0 \%$ (6/24) of the patients; $37.5 \%$ (9/24) of those children underwent cisternal puncture due to seizures. With regard to the premature child group, nontraumatic puncture, the age ranged between 0 and 27 days, being the median 6 days, and the gestational age ranged between 28 and 37 weeks, being the median 32 weeks. CSF examination was performed on account of probable infection, whether due to fever presence, leukocytosis or leukopenia in $74.3 \%$ (26/35) of the patients; 24 children had 
proved infection: sepsis was diagnosed in $14.3 \%$ (5/35) of the cases, and restricted infection like pneumonia $(\mathrm{N}=2)$, bacterial dermatitis $(\mathrm{N}=2)$, necrotizing enterocolitis $(\mathrm{N}=2)$, omphalitis $(\mathrm{N}=1)$, other causes $(\mathrm{N}=12)$ in $54.3 \%(19 / 35) ; 17,1 \%(6 / 35)$ of those children underwent cisternal puncture due to seizures.

By comparing CSF parameters between full-term gestation neonate group with premature neonate one, nontraumatic puncture $\left(\mathrm{RBC}=0 / \mathrm{mm}^{3}\right)$, the mean $\mathrm{WBC}$ counts were analogous $(0.6<\mathrm{p}$ $<0.7$ ), being two standard deviations above the mean and $90^{\text {th }}$ percentile a little bit greater in the premature infant group. PMNs were present in less than $40.0 \%$ of all CSF exams analyzed in each group of children $(37.5 \%$ and $19.4 \%)$; these proportions were not significantly different $(0.2<\mathrm{p}<$ $0.3)$. The mean percentage neutrophil count was significantly greater in the full-term newborn group $(0.01<\mathrm{p}<0.02)$; the mean ANC was less than $1 / \mathrm{mm}^{3}$ in both groups, and the difference between the means of each group was not significant $(0.1<\mathrm{p}<0.2)$; only one patient in each group had ANC $>1$ / $\mathrm{mm}^{3}$ : one full-term gestation neonate that underwent cisternal puncture on his first life day, on account of intact meningocele, whose WBC count was 13 cells/ $\mathrm{mm}^{3}, 39.0 \% \mathrm{PMN}$, glucose $61 \mathrm{mg} /$ $\mathrm{dl}$, protein $94 \mathrm{mg} / \mathrm{dl}$; he was discharged well, without any clinically or clearly proved laboratory infection; one premature 32 week neonate that underwent cisternal puncture on his sixth life day, on account of sepsis and whose WBC count was 28 cells $/ \mathrm{mm}^{3}$, with $5 \%$ PMN, glucose $93 \mathrm{mg} / \mathrm{dl}$, protein $122 \mathrm{mg} / \mathrm{dl}$ was also discharged well. The mean protein concentration was significantly greater in those premature neonates $(0.02<\mathrm{p} 0.04)$. The mean glucose concentration was just the same in both groups $(67 \mathrm{mg} / \mathrm{dl})$ (Table 1). CSF glucose to blood glucose ratio was not calculated because they were not performed at the same time.

By comparing CSF parameters in traumatic puncture with nontraumatic puncture performed on full-term gestation neonates, the mean glucose concentration was significantly lesser in the traumatic puncture group $(0.02<\mathrm{p}<0.04)$ (Table 2$)$. Regarding premature neonates, the mean protein concentration was significantly greater in the traumatic puncture group $(0.04<\mathrm{p}<0.05)$. The glucose concentration was also lesser in these children but the difference was not significant (Table 3 ).

\section{DISCUSSION}

The proper interpretation of CSF results depends on knowledge of normal values in the group of patients being evaluated ${ }^{3,4,15,16}$. Several authors have pointed out that there is an acceptable variability in the CSF profile, especially CSF WBC count, in neonates ${ }^{1,3-5,8-15}$. Furthermore, early detection of neonatal meningitis is a continuing concern in the Neonatal Intensive Care unit ${ }^{2}$.

In this study, we evaluated the variability of CSF findings in a group of neonates who were felt to be sick enough to warrant CSF examination but who were found to have disease unrelated to CNS infection or congenital infection, comparing full-term gestation infants with preterm infants. Moreover, from these children we selected a group of patients who underwent nontraumatic puncture (RBC/ $\mathrm{mm}^{3}=0$ ). We think that for these patients it is desirable that we should have normal values established.

In both full-term gestation neonate group and premature neonate one, we found a great variability of WBC count but the mean, median, $90^{\text {th }}$ percentile were comparable; those values were lesser than those found by Bonadio et al. ${ }^{5}$ and Sarff et al. ${ }^{4}$, studying a similar group of patients. These authors included traumatic punctures in their analysis (RBC up to $1000 / \mathrm{mm}^{3}$ or RBC up to $45000 / \mathrm{mm}^{3}$, respectively). Several studies showed that the average CSF WBC count is 6 to 7 cell/ $\mathrm{mm}^{3}$ in neonates but these studies evaluated healthy neonates ${ }^{8-14}$; this is very close to the results we found $\left(4.5 / \mathrm{mm}^{3}\right.$ and $\left.5.1 / \mathrm{mm}^{3}\right)$. The standard deviations were of the same magnitude as the means, or even greater, which is a reflection of the skewness of these distributions. Although there is a range of normal values, even a greater number of cells may be normal $\left(28 \mathrm{WBC} / \mathrm{mm}^{3}\right)$. $\mathrm{Luz}^{6}$, studying a full-term gestation and normal neonate group, found that the CSF WBC count can be up to $12 \mathrm{WBC} /$ $\mathrm{mm}^{3}$ and the protein concentration can be up to $120 \mathrm{mg} / \mathrm{dl}$; although this author studied CSF samples with up to $600 \mathrm{RBC} / \mathrm{mm}^{3}$, these values are close to ours (Table 1 and 2). The presence of PMN in CSF samples from normal neonates has already been described ${ }^{17}$. As these cells are normally absent 
Table 1. Cerebrospinal fluid values in full-term gestation and premature neonates.

\begin{tabular}{|c|c|c|c|}
\hline & Full-term gestation & Premature & $\mathrm{p}$ \\
\hline \multicolumn{4}{|l|}{$\mathrm{WBC}$ count $/ \mathrm{mm}^{3}$} \\
\hline No. of infants & 25 & 38 & \multirow{7}{*}{$0.6<\mathrm{p}<0.7$} \\
\hline Mean & 4.5 & 5.1 & \\
\hline Median & 3.3 & 3.0 & \\
\hline $\mathrm{SD}$ & 3.6 & 5.8 & \\
\hline Range & $0.3-13$ & $0.3-28$ & \\
\hline $\pm 2 \mathrm{SD}$ & $0-11.7$ & $0-16.7$ & \\
\hline $90^{\text {th }}$ percentile & 8.7 & 9.3 & \\
\hline \multicolumn{4}{|l|}{ Percentage PMNs } \\
\hline No. of infants & 24 & 36 & \multirow{8}{*}{$\begin{array}{c}0.2<\mathrm{p}<0.3 \\
0.01<\mathrm{p}<0.02\end{array}$} \\
\hline Presence of PMNs & $9 / 24(37.5 \%)$ & $7 / 36(19.4 \%)$ & \\
\hline Mean & 4.2 & 0.6 & \\
\hline Median & 0 & 0 & \\
\hline $\mathrm{SD}$ & 8.6 & 1.5 & \\
\hline Range & $0-39$ & $0-6$ & \\
\hline $\pm 2 \mathrm{SD}$ & 21.4 & 3.6 & \\
\hline $90^{\text {th }}$ percentile & 11 & 2 & \\
\hline \multicolumn{4}{|l|}{$\mathrm{ANC} / \mathrm{mm}^{3}$} \\
\hline No. of infants & 24 & 36 & \multirow{7}{*}{$0.1<\mathrm{p}<0.2$} \\
\hline Mean & 0.3 & 0.06 & \\
\hline Median & 0 & 0 & \\
\hline $\mathrm{SD}$ & 1.0 & 0.2 & \\
\hline Range & $0-5.07$ & $0-1.4$ & \\
\hline $\pm 2 \mathrm{SD}$ & 2.3 & 0.46 & \\
\hline $90^{\text {th }}$ percentile & 0.40 & 0.03 & \\
\hline \multicolumn{4}{|l|}{ Protein (mg/dl) } \\
\hline No. of infants & 25 & 37 & \multirow{5}{*}{$0.02<\mathrm{p}<0.0<$} \\
\hline Mean & 77.6 & 101.2 & \\
\hline $\mathrm{SD}$ & 31.5 & 45.7 & \\
\hline Range & $29-160$ & $27-260$ & \\
\hline $90^{\text {th }}$ percentile & 113 & 148 & \\
\hline \multicolumn{4}{|l|}{ Glucose (mg/dl) } \\
\hline No. of patients & 25 & 37 & \multirow{5}{*}{$\mathrm{p}>0.9$} \\
\hline Mean & 67 & 67 & \\
\hline $\mathrm{SD}$ & 25.6 & 33.1 & \\
\hline Range & $38-179$ & $30-194$ & \\
\hline $90^{\text {th }}$ percentile & 76 & 80 & \\
\hline
\end{tabular}

in CSF samples from older children and adults, and these cells are usually associated with inflammation,we studied the amount of them, trying to determine cutoff normal values. The mean percentage PMN count in the full-term neonate group was greater than the mean percentage PMN count in the premature neonate one; this was due to the patient whose diagnosis was intact meningocele. Just one patient in each group had ANC $>1 / \mathrm{mm}^{3}$; the CSF mean ANC values $(0.3$ / $\mathrm{mm}^{3}$ in full-term neonates and $0.06 / \mathrm{mm}^{3}$ in premautre neonates) are both much lesser than documented before ${ }^{1,5}$; PMN leukocytes in the CSF may occasionally be a normal finding, but their presence should not be taken lightly, especially if ANC is $\geq 1 / \mathrm{mm}^{3}{ }^{15}$. The mean protein concentration was significantly greater in the premature group and this is probably due to the more immature bloodbrain barrier in these children when compared with full-term gestation neonates $(0.02<p<0.04)^{18-20}$ this parameter in both groups was slightly lesser than those previously reported in the literature $e^{4,5,7}$. The mean glucose concentration was just the same in both groups. 
Table 2. Comparison of CSF values among full-term gestation neonates: nontraumatic puncture $X$ traumatic puncture up to $500 \mathrm{RBC} / \mathrm{mm}^{3}$.

\begin{tabular}{|c|c|c|c|}
\hline & $\begin{array}{l}\mathrm{RBC}=0 \\
(\mathrm{~N}=25)\end{array}$ & $\begin{array}{c}\mathrm{RBC}<500 / \mathrm{mm}^{3} \\
\quad(\mathrm{~N}=5)\end{array}$ & $\mathrm{p}$ \\
\hline \multicolumn{4}{|l|}{ WBC count $/ \mathrm{mm}^{3}$} \\
\hline Mean & 4.5 & 6.3 & $0.3<\mathrm{p}<0.4$ \\
\hline SD & 3.6 & 7.1 & \\
\hline Neutrophil presence & $9 / 24(37,5 \%)$ & $2 / 5(40,0 \%)$ & $\mathrm{p}=0.38$ \\
\hline \multicolumn{4}{|l|}{ Protein (mg/dl) } \\
\hline Mean & 77.6 & 65.4 & $0.4<\mathrm{p}<0.5$ \\
\hline SD & 31.5 & 11.3 & \\
\hline \multicolumn{4}{|l|}{ Glucose $(\mathrm{mg} / \mathrm{dl})$} \\
\hline Mean & 66.9 & 38.6 & $0.02<p<0.04$ \\
\hline SD & 25.6 & 9.2 & \\
\hline
\end{tabular}

Table 3. Comparison of CSF values among premature neonates: nontraumatic puncture X traumatic puncture up to $500 \mathrm{RBC} / \mathrm{mm}^{3}$.

\begin{tabular}{lccc}
\hline & $\begin{array}{c}\mathrm{RBC}=0 \\
(\mathrm{~N}=38)\end{array}$ & $\begin{array}{c}\mathrm{RBC}<500 / \mathrm{mm}^{3} \\
(\mathrm{~N}=9)\end{array}$ & $\mathrm{p}$ \\
\hline $\begin{array}{l}\text { WBC count/mm } \\
\quad \text { Mean }\end{array}$ & 5.1 & 9.6 & $0.10<\mathrm{p}<0.20$ \\
$\quad$ SD & 5.8 & 13.6 & \\
Neutrophil presence & $7 / 36(19.4 \%)$ & $2 / 8(25.0 \%)$ & $\mathrm{p}=0.33$ \\
Protein (mg/dl) & & & \\
$\quad$ Mean & $101.2^{*}$ & 134.6 & $0.04<\mathrm{p}<0.05$ \\
SD & $45.7^{*}$ & 34.2 & \\
Glucose (mg/dl) & & & $0.10<\mathrm{p}<0.20$ \\
$\quad$ Mean & $67.0^{*}$ & 49.4 & \\
SD & $33.0^{*}$ & 23.1 & \\
\hline
\end{tabular}

$* \mathrm{~N}=37$

When we compared traumatic puncture with nontraumatic puncture, we found that the mean glucose concentration was significantly lesser when the puncture was traumatic $(0.02<p<0.04)$ in full-term gestation neonates; in premature neonates the mean glucose concentration was also lesser in the traumatic puncture group but the difference was not significant $(0.10<p<0.20)$; it is possible that some of the patients included in the group of traumatic puncture were in fact patients with CNS hemorrhage what could explain the lower glucose concentrations ${ }^{3}$; the mean protein concentration was greater in children who underwent traumatic puncture in the premature neonate group $(0.04<\mathrm{p}<0.05)$. These data show how traumatic puncture, even with $\mathrm{RBC}$ up to $500 / \mathrm{mm}^{3}$, interferes on CSF analysis and changes its parameters. Especially in neonates, it is a common shortcoming. Neonates have a very narrow lumbar sac along with very tender meningeal tissue and blood vessels which might facilitate needle trauma. Furthermore, the dura mater displacement provoked by the needle during the puncture might increase the chance of trauma ${ }^{21,23}$. As the cisterna magna is larger than the lumbar sac in neonates, cisternal CSF puncture might prevent trauma of vessels. However, a cisternal puncture might be harzardous to the patient if it is performed by a skilless physician.

It had also been reported that patients who are first seen with seizures have a CSF pleocytosis as the result of the seizure itself ${ }^{24}$. Besides that, patients with seizures do form a large proportion of those 
patients undergoing lumbar/cisternal puncture. As Portnoy and Olson ${ }^{1}$ demonstrated that children with seizures did not have increased numbers of WBCs in their CSF, we included those patients in our study (37.5\% in full-term gestation neonate group and $17.1 \%$ in premature neonate one).

The CSF profile, like any other laboratory determination, should be evaluated within the clinical context of the individual case. Regarding neonates, the majority of these infants with noninfected CSF have an ANC $<1 / \mathrm{mm}^{3}$; the total WBC count of noninfected CSF is $\leq 11.7 / \mathrm{mm}^{3}$ in the full-term neonate group and $\leq 16.7 / \mathrm{mm} 3$ in the premature neonate one. The mean CSF protein concentration is significantly greater in those premature neonates compared with those full-term gestation neonates. Traumatic puncture, even up to $500 \mathrm{RBC} / \mathrm{mm}^{3}$, interferes on CSF parameters. This is the first study concerning high-risk neonates (comparing full-term gestation neonates with premature ones) with noninfected CSF obtained by nontraumatic puncture $\left(\mathrm{RBC} / \mathrm{mm}^{3}=0\right)$.

Acknowledgments - We thank Dras. Ana Suely Neves and Rosana Pelegrini for allowing us to review clinical chart at Santo Amaro Hospital, Português Hospital, Salvador Hospital (Neonatal Intensive Care Units).

\section{REFERENCES}

1. Portnoy JM, Olson LC. Normal cerebrospinal fluid values in children: another look. Pediatrics 1985;75:484-487.

2. Visser VE, Hall RT. Lumbar puncture in the evaluation of suspected neonatal sepsis. J Pediatr 1980;96:1063-1067.

3. Fishman RA. CSF findings in diseases of the nervous system. In Fishman RA. Cerebrospinal fluid in diseases of the nervous system. 2Ed. Philadelphia: W.B. Saunders, 1992:253-255.

4. Sarff LD, Platt LH, McCracken GH. Cerebrospinal fluid evaluation in neonates: comparison of high-risk infants with and without meningitis. J Pediatr 1976;88:473-477.

5. Bonadio WA, Stanco L, Bruce R, Barry D, Smith D. Reference values of normal cerebrospinal fluid composition in infants ages 0 to 8 weeks. Pediatr Infect Dis J 1992;11:589-591.

6. Luz BR. Contribuição para o estudo da xantocromia do líquido cefalorraqueano de recém-nascidos normais. Tese. Faculdade de Medicina da Universidade de São Paulo. São Paulo, 1972.

7. Vaz FAC, Livramento JA, Spina-França A .Líquido cefalorraqueano no recém-nascido pré-termo sadio. Arq Neuropsiquiatr 1977;35:183-188.

8. Naidoo BT. The cerebrospinal fluid in the healthy newborn infant. S Afr Med J 1968;42:933-935.

9. Otila E. Studies on the cerebrospinal fluid in premature infants. Acta Paediatr 1948;35(Suppl 8):3-100.

10. Roberts MH. The spinal fluid in the newborn with especial references to intracranial hemorrhage. JAMA 1925;85:500.

11. Samson K. Die Liquordiagnostik im Kindesaltor. Ergeb Inn Med Kinderheilkd 1931;41:665-679.

12. Waitz R. Le liquide cephalorachidien du nouveau-né. Rev Franç Pediatr 1928;4:1-56.

13. Widell S. On the cerebrospinal fluid in normal children and in patients with acute abacterial meningoencephalitis. Acta Paediatr 1958; 47(Suppl 115):1-102.

14. Wyers HJG, Bakker JCW. De liquor cerebrospinalis van normale, a terme geboren neonat. Maandschrift Kindergenceskunde 1954; 22:253-256.

15. Bonadio WA. The cerebrospinal fluid: physiologic aspects and alterations associated with bacterial meningitis. Pediatr Infect Dis J 1992; 11:423-431.

16. Bonadio WA, Smith D. CBC differential profile in distinguishing etiology of neonatal meningitis. Pediatr Emerg Care 1989;5:94-96.

17. Diniz EMA, Spina-França A, Livramento JA, et al. Líquido cefalorraquídeo de recién nacidos pretérmino durante el período neonatal. II. Estudio citomorfológico. Bol Méd Hosp Infant Méx 1982; 39:409-412.

18. Fishman RA. Blood-brain barrier in pathological conditons. In Fishman RA. Cerebrospinal fluid in diseases of the nervous system. 2.Ed. Philadelphia: W.B. Saunders, 1992:69.

19. Diniz EMA, Spina-França A, Livramento JA, et al. Líquido cefalorraquídeo de recién nacidos pretérmino durante el período neonatal I. Aspectos bioquímicos. Bol Méd Hosp Infant Méx 1982;39:253-257.

20. Diniz EMA, Spina-França A, Livramento JA, et al. Líquido cefalorraquídeo de recién nacidos pretérmino durante el período neonatal III. Estudio proteínico. Bol Méd Hosp Infant Méx 1982;39:473-476.

21. Hasue M, Kikuchi A, Sakuyama R, Ito T. Anatomic study of the interrelation between lumbossacral nerve roots and their surrounding tissues. Spine 1983;8:50-58.

22. Rossitti SL, Araújo JFM, Sperlescu A, Balbo RJ. Observações sobre o deslocamento da dura-máter nas punções cisternais laterais. Arq Neuropsiquiatr 1990;48:469-472.

23. Rossitti SL, Thomaz IG, Balbo RJ. Mensuração do deslocamento da dura-máter na punção suboccipital mediana. Arq Neuropsiquiatr 1991;49:307-309.

24. Schmidley JW, Smon RP. Postictal pleocytosis. Ann Neurol 1981;9:81-84. 